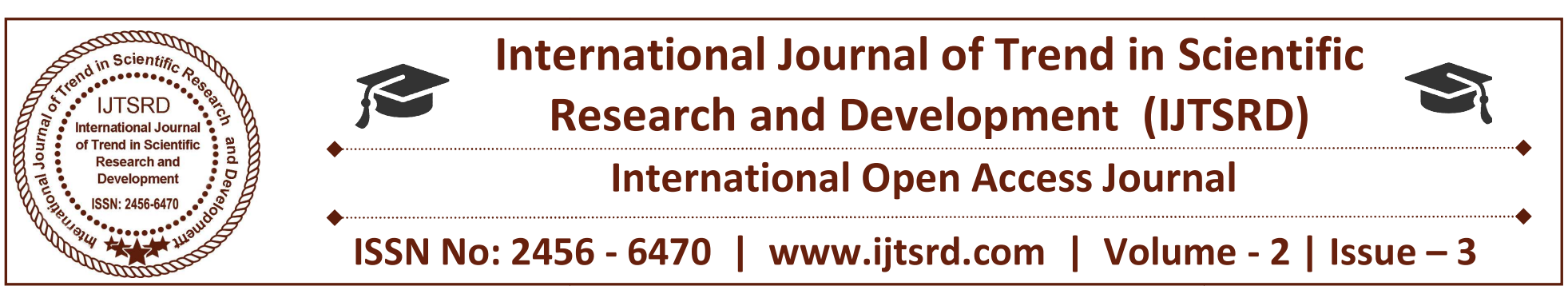

\title{
Simultaneous saccharification and fermentation of acid pretreated Shorea robusta for bioethanol production
}

\author{
Ankita Choudhary, S. K. Jadhav*, K. L. Tiwari \\ School of Studies in Biotechnology, Pandit Ravishankar Shukla University, \\ Raipur Chhattisgarh, India
}

\begin{abstract}
Ethanol is a renewable biofuel produced through fermentation of sugars, starch and lignocellulosic biomass. Lignocellulosic feedstocks are cheap, abundant, renewable source of energy. In this work, Shorea robusta has been utilized for the bioethanol production by the process of simultaneous saccharification and fermentation (SSF). Phanerocheate chrysosporium was used for saccharification process and fermentative ethanol production was done by Klebsiella pneumoniae UT3. To evaluate the role of fermentation parameters (temperature and $\mathrm{pH}$ ) on ethanol production was optimized. A high amount of ethanol was obtained at optimized conditions of temperature and $\mathrm{pH}$ i.e. $10 \%$ $(\mathrm{v} / \mathrm{v})$ and $9.5 \%(\mathrm{v} / \mathrm{v})$ respectively.
\end{abstract}

\section{Keywords: Bioethanol, Lignocellulosic,}

Phanerocheate chrysosporium, Shorea robusta.

\section{Introduction}

The production of bioethanol from lignocellulosic biomass is an alternative to fossil fuel energy resources. Conversion of abundant lignocellulosic biomass to biofuels presents a viable option for improving the energy security and reducing the emission of green house gases (Wyman 1999). Lignocellulose is the major structural component of the plant biomass and represents major part of renewable organic matter. Lignocellulosic biomass is primarily composed of carbohydrates (cellulose and hemicellulose), lignin, and other extraneous components (proteins, lipids, and inorganic substances) (Kim, 2013). Cellulose is the main structural constituent of cell wall; a linear polymer consisting of D-glucose units linked to each other by $\beta$ (1-4 glycosidic bond). The long chain of cellulose polymer are linked together by hydrogen and van der Waals bonds, which cause the cellulose to packed into microfibrils. Lignin is a heterogeneous, cross linked three dimensional phenyl propane polymer, that acts as a cementing material and closely associates with cellulose and hemicelluloses. This imparts structural crystallinity thereby making the biomass recalcitrant in nature (Amiri and Krimi, 2013). The basic step in the production of bioethanol from lignocellulosic material is pretreatment. Pretreatment can effectively overcome both chemical and physical barriers and enhance the enzymatic digestibility of biomass (Kim et al, 2016).

The goal of pretreatment is to disrupt the cell wall matrix to make it amenable to enzymatic hydrolysis. Enzymes produced by variety of microorganisms are capable of breaking the lignocellulosic material to sugars but with longer retention time. At the same time, enzymatic hydrolysis is the most common method of producing ethanol from the lignocellulosic biomass. Conversion of lignocellulosic material to ethanol involves mainly four steps: (1) pretreatment, (2) enzymatic hydrolysis, (3) fermentation of sugars to ethanol, and (4) distillation and purification (Nitos et al. 2013, Kim et al. 2016). Acid pretreatment has been extensively studied to disrupt the rigid structure of biomass. Acid hydrolysis mainly utilizes sulphuric acid $\left(\mathrm{H}_{2} \mathrm{SO}_{4}\right)$ and hydrochloric acid $(\mathrm{HCl})$, that causes solulization of hemicelluloses altering the structural complexity (Brodeur et al. 2011; Pu et al. 2013; Silverstein et al. 2007) causes delignification, increases accessible surface area of the substrate (Kim et al, 2012). 


\section{Materials and methods}

Sample collection: Shorea robusta (Sal) seeds were collected from Village Sargipal, Bakawand range, Jagdalpur forest region, Chhattisgarh India.

Physical pretreatment: Sample was grinded for size reduction to $0.2 \mathrm{~mm}$ size and was further dried in oven at $40^{\circ} \mathrm{C}$ for 2 hours.

Chemical (acid) pretreatment: $1.5 \%(\mathrm{v} / \mathrm{v})$ of hydrochloric acid was added to physically pretreated Shorea robusta substrates. The sample was left for 24 hours at room temperature. The mixture was filtered washed to neutrality with distilled water, oven dried at $40{ }^{0} \mathrm{C}$ to a constant weight and then milled to powder, further used for fermentation.

Simultaneous saccharification and fermentation: The chemically treated biomass was added with Phanerocheate chrysosporium followed by Klebsiella pneumoniae UT3. After the saccharification process, reducing sugar estimated by DNS (Dinitro-Salicylate) method (Miller, 1989).

Optimization of parameters: To evaluate the effects on fermentation process the physical parameter temperature and $\mathrm{pH}$ was optimized. The SSF was carried at temperature $25{ }^{0} \mathrm{C}, 30{ }^{0} \mathrm{C}, 35{ }^{0} \mathrm{C}, 40{ }^{0} \mathrm{C}$. A similar study was performed with different $\mathrm{pH}$ of 5,6 , 7.

Fractional distillation and estimation: The fermented samples were transferred into round bottom flask fixed to a distillation column with running tap water for cooling. A conical flask was fixed to a distillation column at the other end to collect the distillate (Maurya et. al, 2015; Nzelibe and Okafoagu, 2007; Oyeleke and Jibrin, 2009). The ethanol content was measured using specific gravity method (Pharmacopoeia of India, 1985). The percent of ethanol was calculated using following formula:

$\rho^{\mathrm{t} 0}=\underline{\mathrm{W}}_{3}-\underline{\mathrm{W}}_{1} \times$ Density of water at $\mathrm{t}^{0}$

$$
\mathrm{W}_{2}-\mathrm{W}_{1}
$$

where $\rho^{\mathrm{t} 0}=$ specific gravity, $\mathrm{W} 1=$ weight of empty specific gravity bottle, W2 = weight of empty bottle + distilled water, $\mathrm{W} 3=$ weight of empty bottle + fermented liquid (Yadav, 2003).

Results: The physical parameters affecting like temperature and $\mathrm{pH}$ have been optimized and increase in the yield of ethanol was recorded. At optimum conditions of temperature the maximum of $10.0 \%$ (v/v) ethanol was achieved at $35{ }^{\circ} \mathrm{C}$ and $9.5 \%(\mathrm{v} / \mathrm{v})$ at $\mathrm{pH} 6$.

Discussions: The digestibility of lignocelluloses is hindered by many structural and compositional factors which require an effective pretreatment to enhance the susceptibility of biomass for hydrolysis and fermentation. It is necessary for the production of ethanol that both the cellulose and hemicellulose should be converted to fermentable sugars that could be efficiently utilized by the microorganisms for the production of ethanol. The main objective of the acid pretreatment is chemical hydrolysis that causes solubilization of hemicelluloses and lignin making the cellulose more accessible to enzymes (Maurya, 2015). Physical pretreatment and dilute acid pretreatmet was the employed for hydrolysis of the substrate. The pretreatment process can remove hemicellulose, reduce cellulose crystallinity, and increase the porosity of the materials. Enzymatic saccharification of chemically treated substrate using Phanerocheate chrysosporium effectively reduces the lignin content and crystallinity of lignocellulosic biomass that usually prevents penetration of cellulase in the lignocellulose that results in low enzymatic activity (Yang et al. 2010). The slow rate of hydrolysis results due to the slow action of enzymes, because of obstacles that interfere with their path or a loss in activity or processivity making them less effective (Yang et al. 2006). During SSF process, enzymatic hydrolysis and fermentation takes place in the same vessel. The simple sugars released during saccharification by Phanerocheate chrysosporium is simultaneously consumed and fermented by Klebsiella pneumoniae UT3. The higher saccharification results in better utilization of fermentable sugars after fungal pretreatment towards fermentation. To better understand the differences among the effects were grouped according to the results of statistical analysis. Temperature plays a significant role in the functional activity and stability of enzymes. All cellular reactions occur at measurable rates due to the presence of enzymes. At optimum temperatures the kinetic energy of molecules increases thereby overcoming the barriers to finally firm the products. The overall results of the work showed that Phanerocheate chrysosporium effectively digests the cellulose and lignin content present in the biomass. Maximum cellulose and lignin degradation occurs at optimum temperature and $\mathrm{pH}$. The results 
indicate that bioethanol can be produced from Shorea robusta by the process of simultaneous saccharification and fermentation.

Table no. 1. Optimization of temperature for bioethanol production by simultaneous saccharification and fermentation

\begin{tabular}{|l|l|l|}
\hline $\begin{array}{l}\text { Sl. } \\
\text { No. }\end{array}$ & $\begin{array}{l}\text { Temperature } \\
\left.{ }^{0} \mathrm{C}\right)\end{array}$ & Ethanol percentage (v/v) \\
\hline 1 & 25 & $5.4 \pm .2^{\mathrm{d}}$ \\
\hline 2 & 30 & $6.4 \pm .1^{\mathrm{c}}$ \\
\hline 3 & 35 & $10.0 \pm .0^{\mathrm{a}}$ \\
\hline 4 & 40 & $7.1 \pm .2^{\mathrm{b}}$ \\
\hline
\end{tabular}

Each step was repeated 3 times. All the values are mean \pm standard error, values differ significantly at $5 \%$ as analyzed by Duncan multiple Range Test by SPSS

Table no. 2. Optimization of $\mathrm{pH}$ for bioethanol production by simultaneous saccharification and fermentation.

\begin{tabular}{|l|l|l|}
\hline $\begin{array}{l}\text { SI. } \\
\text { No. }\end{array}$ & pH & Ethanol percentage $(\mathrm{v} / \mathrm{v})$ \\
\hline $\mathbf{1}$ & 5 & $6.6 \pm .3^{\mathrm{c}}$ \\
\hline $\mathbf{2}$ & 6 & $9.5 \pm .0^{\mathrm{a}}$ \\
\hline $\mathbf{3}$ & 7 & $8.2 \pm .0^{\mathrm{b}}$ \\
\hline
\end{tabular}

Each step was repeated 3 times. All the values are mean \pm standard error, values differ significantly at $5 \%$ as analyzed by Duncan multiple Range Test by SPSS

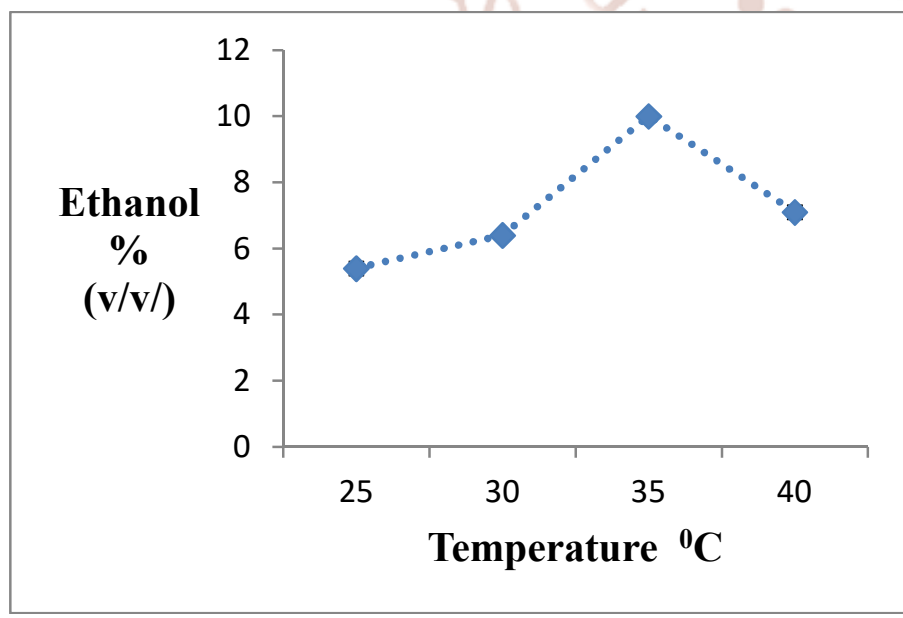

Fig 1. Optimization of temperature for bioethanol production by simultaneous saccharification and fermentation.

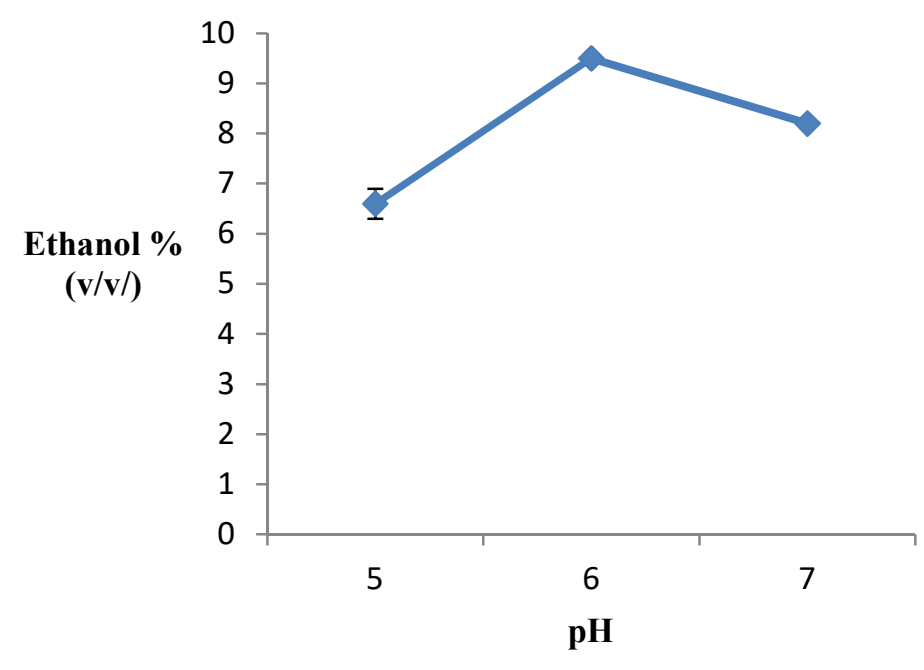

Fig 2. Optimization of $\mathrm{pH}$ for bioethanol production by simultaneous saccharification and fermentation

\section{Conclusions}

Utilization of renewable substrate for the production of bioethanol is the viable and best alternative to the fossil fuels. For fulfilling the world's energy demand, exploring more renewable sources has opened new doors for conserving the environment. Use of lignocellulosic biomass for ethanol production mitigates the release of green house gases especially carbon- di-oxide in the environment. Thus, it contributes to green and clean energy for the sustainable development of the society.

Acknowledgement: Author is grateful to Head, School of Studies in Biotechnology, Pt. Ravishankar Shukla University Raipur, Chhattisgarh, India for providing research facilities and valuable guidance for research work. I acknowledge DST INSPIRE, New Delhi (No.

DST/INSPIRE Fellowship/2015/IF150194) for providing me financial support for my research work.

\section{References:}

1) Amiri, H. Karimi, K. 2013, Efficient Dilute-Acid Hydrolysis of Cellulose Using Solvent Pretreatment, Industrial \& Engineering Chemistry Research, 52: 11494-11501.

2) Brodeur, G., Yau, E., Badal, K., Collier, J., Ramachandran, K. B., \& Ramakrishnan, S. 2011. Chemical and physicochemical pretreatment of lignocellulosic biomass: A review. Enzyme Research, http://dx.doi.org/10.4061/2011/787532Chen 
3) Kim, B. Gulati, I. Park, J. Shin, J. S. 2012. Pretreatment of cellulosic waste sawdust into reducing sugars using mercerization and etherification. Bioresources, 7(4): 5152-5166.

4) Kim, J. S. Lee, Y.Y. and Kim T. H. 2016. A review on alkaline pretreatment technology for bioconversion of lignocellulosic biomass. Bioresource Technology, 199: 42-48.

5) Maurya, D. P., Singla, A. and Negi, S. 2015. An overview of key pretreatment processes for biological conversion of lignocellulosic biomass to bioethanol. 3 Biotech, 5: 597-609.

6) Nitsos, C. K., Matis, K. A., \& Triantafyllidis, K. S. (2013). Optimization of hydrothermalpretreatment of lignocellulosic biomass in the bioethanol production process.Chem Sus Chem, 6(1): 110-122.

7) Nzelibe, H.C.N. Okafoagu, U.C. 2007. Optimization of ethanol production from garcinia kola (bitter kola) pulp Agro Waste, African Journal of Biotechnology, 6(17): 2033-2037.

8) Oyeleke, S.B. Jibrin, N.M. 2009. Production of ethanol from guinea cornhusk and millet husk. African Journal of Microbiology Research, 3(4): $147-152$.

9) Pharmacopoeia of India (1985) The Indian pharmacopoeia. Published by the Controller of publications. 3rd edn, vol 2, pp 113-115.

10) $\mathrm{Pu}, \mathrm{Y}$., Hu, F., Huang, F., Davison, B., \& Ragauskas, A. (2013). Assessing the molecularstructure basis for biomass recalcitrance during dilute acid and hydrothermalpretreatments. Biotechnology for Biofuels, 6(1), 15.

11) Silverstein, R. A. Chen, Y. Shivappa, S. Boyette, M. D. Osborne, J. 2007. A comparison of chemical pretreatment methods for improving saccharification of cotton stalks. Bioresource Technology, 98(16): 3000-3011.

12) Wyman C. E. 1999 Biomass ethanol: Technical progress, oppurtunities and commercial challenges. Annu. Rev. Energy Environment, 24: 189-226.

13) Yadav JB (2003) Advanced practical, physical chemistry. Goel publication house. Krishna Prakashan Media (P) Ltd., Meerut, pp 52-56

14) Yang, B. Willies, D. M. and Wyman, C.E. 2006. Changes in the enzymatic hydrolysis rate of avicel cellulose with conversion. Biotechnol. Bioeng, 94(6): 1122-1128.

\section{.}

